\title{
CIRKEVNÝ DESIATOK MEDZI OPÁTOM A BISKUPOM. K SPOROM O ŠOMODSKÉ DESIATKY V 13. STOROČÍ1
}

\author{
The Church Tithes Between Abbots and Bishops. \\ On the 13th-Century Disputes Over Somogy Tithes
}

\author{
Marek Druga
}

DOI: 10.17846/CL.2020.13.2.65-75

\begin{abstract}
DRUGA, Marek. The Church Tithes Between Abbots and Bishops. On the 13th-Century Disputes Over Somogy Tithes. The study deals with the circumstances and broader context of the comita tus Somogiensis tithe disputes between the Pannonhalma abbots and the Veszprem (to a lesser extent Zagreb) bishops in the 13th century. It introduces the circumstances of the Somogy tithe donation, which was granted to the Pannohalma Abbey by King Stephen, and the gradual legal anchoring of religious tithes in Hungarian legislation. Following the introduction of the broader context, which had helped to form the bishops' claim for the tithes, the study proceeds to focus on the circumstances of specific court trials, then on the mechanisms of asserting and securing the bishops' and abbots' claims for the tithes and, finally, on the methods of solving particular disputes. The study demonstrates the wide range of ways, in which bishops and abbots prevailed in disputes. Bishop from Veszprém based his claims on the right of bishops to tithes. This right was already secured by canonic law and by the Hungarian royal laws of the kings of St. Stephen, St. Ladislav and Coloman. On the other hand, abbot from Pannonhalma monastery Urias tried to enforce his claims with the false charter of Pannonhalma abbacy and with the authority of the king St. Stephen. The study thus emphasizes the unique confrontation between bishops and abbots in the disputes over the whole comitatus tithes.
\end{abstract}

Keywords: Pannonhalma, tithes, abbas, bishop, law-suit

V poslednej dobe opätovne rozvírila vody madarskej medievalistiky problematika šomodských desiatkov, ktoré mal darovat' Pannonhalmskému kláštoru pri jeho založení král sv. Štefan. Témou na diskusiu sa tentokrát stala zmienka rábskeho biskupa Hartvika o každom desiatom diełati darovanom opátstvu v rámci desiatku (Lados 2016, 73-98; Solymosi 2016, 11-24). Šomodské desiatky pritom pútajú pozornost' historickej vedy z viacerých perspektív. Do okruhu záujmu madarských medievalistov sa dostávajú predovšetkým okolnosti vzniku donácie a rozsah cirkevných právomocí opátov a biskupov na území Šomodského komitátu. ${ }^{2}$ Nasledujúce riadky predstavujú skôr pokus o pohlad na početné spory, ktoré nároky opátov či biskupov na príjmy z desiatkov nevyhnutne vyvolávali. Pozornost bude v príspevku zameraná na okolnosti, ktoré pôsobili ako podnety súdnych sporov, na mechanizmy presadzovania a zabezpečovania nárokov na desiatky

Táto práca bola podporená agentúrou VEGA v rámci projektu: VEGA 2/0129/18: Panovnícka moc v stredoveku. Vývoj panovníckej moci od velkomoravských kniežat po uhorských králov neskorého stredoveku.

2 K otázke údajných biskupských právomocí Pannonhalmy na území Šomodského komitátu pozri bližšie Kristó 2002, 449-453; Zsoldos 2002a, 451-461; Zsoldos 2002b, 471-477; Solymosi 2002, 439-448. 
a čiastočne na efektivitu zavádzania normatívnych opatrení do praxe. Do popredia sa teda budú dostávat predovšetkým výrazne interpolované privilegiálne listiny z prelomu 10./11. storočia, pápežské a panovnícke konfirmácie starších písomností, ale aj rozhodnutia dalších predstavitelov súdnej moci, ktoré do tohto (v uhorských pomeroch) ojedinelého stretu o právo na komitátne desiatky zasahovali. Spory o šomodské desiatky síce nevznikali len v stretoch opátov s biskupmi, v texte však bude dôraz kladený predovšetkým na konfrontáciu opát - biskup.

$\mathrm{Na}$ úvod bude vhodné pristavit’ sa aspoň v krátkosti pri okolnostiach vzniku nárokov pannonhalmských opátov na šomodské desiatky. Podla údajnej privilegiálnej listiny krála Štefana z roku 1001 (1002?) postavil (či skôr dokončil) panovník na Panónskom vrchu kláštor sv. Martina. Na zaopatrenie mníchov daroval opátstvu desiatky podrobeného šomodského obyvatelstva, ktoré pozostávali zo všetkých vecí či produktov práce (de omnibus negociis), statkov (praediis), pôdy (terris), viníc (vineis), sejby (segetibus), mýt (vectigalibus) či vína hostí (vinumque hospitum) (Györffy 1992, 40, č. 5/II). Štefan uskutočnil donáciu údajne z vdačnosti za pomoc sv. Martina pri porážke odboja Šomodského komitátu (v skutočnosti šomodského kniežata Kopáňa). V mad’arskej historickej vede prevláda názor, že $\mathrm{k}$ darovaniu desiatkov prišlo v čase založenia kláštora. Naproti tomu sa v príspevku o okolnostiach vzniku donácie snažím poukázat' na nezrovnalosti, ktoré sa s takouto interpretáciou prameňov spájajú. Len tažko si totiž v čase prakticky neexistujúcej cirkevnej správy predstavit ako hlavnú zložku hmotného zaopatrenia mníšskej komunity predchádzajúcou skúsenostou neoverenú a úradným aparátom včasnostredovekého štátu logisticky sotva zvládnutelnú položku. Šomodský komitát sa navyše nespomína ani pri vymedzení diecézneho územia Vesprímskeho biskupstva z roku 1009, čo vyvoláva vážne pochybnosti o jeho skoršom zriadení ako politicko-správnej jednotky, a tým aj o autentickosti časti privilegiálnej listiny pre Pannonhalmu, ktorá sa venuje desiatkom. V Menšej svätoštefanskej legende (Legenda minor Sancti Stephani regis) sa navyše zachovali pravdepodobne zlomky staršej vrstvy informácií o obdarovaní Pannonhalmského kláštora. Autor hagiografie uvádza, že Štefan učinil z podrobeného obyvatel'stva služobníkov kláštora a až neskôr, údajne na radu svojho blízkeho okolia, obmedzil pôvodné rozhodnutie len na výber desiatkov. Za zmienku stojí aj samotná podstata votívneho daru sv. Martinovi (votum Sancto Martino). Donácia Štefana totiž spočívala v očakávaní pomoci svätca v nadchádzajúcom boji s Kopáňom $\mathrm{v}$ prípade donácie cirkevných desiatkov by tak protihodnota za túto pomoc spočívala v platbe, ktorej by sa Štefan nevzdával ani z panovníckych, teda vlastných príjmov. Domnievam sa, že pôvodne mohli plynút Pannonhalme z územia porazeného šomodského kniežata skôr príjmy, ktoré sa viazali na práva pannonhalmských opátov ako cirkevných zemepánov a zároveň držitelov panovníkom prepustených dávok zdaneného obyvatelsstva. Domnienku argumentačne podopiera aj silné majetkové zázemie opátstva na šomodskom území, ktoré preukázatel’ne siaha už do 11. storočia. Až niekedy po roku 1009, ked’ sa postupne stávali desiatky stabilnou a stále významnejšou súčastou príjmov cirkevných inštitúcií (na prvom mieste biskupstiev), sa tak mohli nároky pannonhalmských opátov definitívne obrátit k cirkevným desiatkom. Tieto nároky opátov mohli byt zároveň presadené v dôsledku silného povedomia o podriadení územia šomodského kniežata a všetkých z neho plynúcich príjmov Pannonhalme. So sformovaním diecézneho územia Vesprímskeho biskupstva, do ktorého sa dostal pravdepodobne až niekedy po roku 1009 aj šomodský región, mohlo prichádzat k prvým prejavom nespokojnosti biskupov a k následnej kompenzácii stratených desiatkov obdarovaním biskupstva královským majetkom alebo dvorcom (Cortou) s príslušnými príjmami a obyvatel'stvom (Druga 2019, 75-88).

Odvádzanie cirkevných desiatkov má dlhú, do neskorej antiky siahajúcu tradíciu. Spočiatku dobrovolné dary prinášané $\mathrm{v}$ košoch $\mathrm{k}$ bránam kostolov postupne nahrádzala desiata čast' úrody veriacich (decimae, decimationes), pričom od konca 5. storočia už nariadenia pápežov Simplicia (468 - 483) a Gelasia (492 - 496) nasmerovali tieto príjmy do rúk biskupov (Érszegi 1996, 5152). Odvod desiatkov ako povinnú platbu cirkvi definovali synodálne nariadenia 6. storočia. 
Niekedy v tomto období možno hladat aj dávne korene všeobecne rešpektovaného zvyku, podla ktorého delil biskup tri štvrtiny desiatkov medzi klérus, chudobu a prostriedky určené na opravu a zveladenie cirkevných stavieb. Jednalo sa o teoretický model, ktorý bol nezriedka zneužívaný samotnými biskupmi, častejšie však vlastníkmi a neskoršími laickými patrónmi kostolov. Výber desiatkov napokon dlhodobo zabezpečoval svetský úradný aparát, nezriedka tak disponovali predovšetkým desiatkami určenými nižšiemu kléru laici. Hoci sa odvádzanie desiatkov pôvodne týkalo všetkých príslušníkov krestanského spoločenstva, povinnost' platit desiatok postupne snímali početné imunity, ktoré smerovali k predstavitelom svetskej nobility a predovšetkým duchovného stavu. Postupné zavádzanie desiatku do uhorskej spoločnosti nachádzalo oporu aj v královskom zákonodarstve. Práve nariadenia panovníkov tak možno označit za právnu záruku vymáhatelnosti tejto biskupom adresovanej platby.

S povinnostou odvádzat cirkevný desiatok sa je možné stretnút už v zákonoch krála sv. Štefana. ${ }^{3}$ 52. kapitola jeho druhej knihy zákonov dalej nariaduje každému, kto by desiatok odovzdat odmietol, zaplatit devätnásobok hodnoty desiatku. ${ }^{4}$ Z kontextu nariadení krála Štefana o desiatkoch dalej vyplýva ich nasmerovanie do rúk episkopátu - každé odcudzenie desiatkov náležiacich biskupom trestá panovník ako krádež, pričom biskupom sa prisudzuje aj právo na celú výšku následnej pokuty. ${ }^{5}$ Konkrétnejšie nariadenia už obsahujú zákony krála Ladislava. Podla jeho prvého zákonníka (nariadenia Szabolcsskej synody z roku 1092) mali platit slobodní desiatky biskupom, kým ludia darovaní do služby cirkvi mali desiatky odvádzat príslušným kostolom, do ktorých farského obvodu patrili. ${ }^{6}$ Zákonodarstvo krála Ladislava zároveň navodzuje dojem volnejšej dispozície biskupa s desiatkami, ked' o povinnosti biskupa postupovat štvrtinu desiatkov miestnemu kléru informuje len $\mathrm{v}$ súvislosti s hospodárskym zvieratstvom, z ktorého prijal biskup desiatok na území inej diecézy. ${ }^{7}$ Szabolcsská synoda už približuje aj spôsob výberu desiatkov. Na ich odvádzanie mali dohliadat úradníci biskupov (pristaldi), v sporných prípadoch pristaldi krála a župana. ${ }^{8} \mathrm{~S}$ odkazom na staro- či novozákonné texty priznáva biskupom desiatok aj zákonodarstvo za vlády krála Kolomana. ${ }^{9}$ Podla I. Kolomanovej knihy zákonov mali smerovat desiatky z viníc opátov a svetského kléru do rúk biskupov, na diecéznom území ktorých bola úroda pestovaná. ${ }^{10}$ II. kniha zákonov krála Kolomana obsahuje zmienku o všeobecnej povinnosti platił desiatky biskupom s výnimkou služobníkov cirkvi, ktorí majú platit’ desiatky kostolom. ${ }^{11}$ Odvádzanie desiatkov upresňuje aj nariadenie I. Ostrihomskej synody, podla ktorej nie je svetský ani reholný klérus

3 „Si cui Deus decem dederit in anno, decimam Deo det“" (Stephanus II, 20. Bak et al. 1999, 11).

4 „Et si quis decimam suam abscondit, novem solvat" (Stephanus II, 20. Bak et al. 1999, 11).

5 „Et si quis decimationem episcopo separatam furatus fuerit, diiudicetur ut fur, ac huiusmodi compositio tota pertineat ad episcopum"(Stephanus II, 20. Bak et al. 1999, 11).

6 „Episcopi de liberis accipiant decimas. Liberi vero, cuicunque episcopo vel comiti adhaeserint, sicut eis placuerit, ita habeantur, salva tamen libertate. Qui autem pro animarum salute libertati mancipati fuerint, eo tenore tamen, ut ecclesiae serviant, ipsi nemini, nisi soli presbytero administrent" (Syn. Szab., 30. Bak et al. 1999, 57).

7 „Episcopi qui decimationem pecorum in alio episcopatu nascentium accipiunt, quartam partem presbyteris in suo episcopatu manentibus tribuant" (Syn. Szab., 33. Bak et al. 1999, 57).

8 Syn. Szab., 33. Bak et al. 1999, 58-59.

9 „De tributis autem et vectigalibus sicut comitibus tertiam partem dari decrevimus, ita decimam quoque episcopis censemus, quibus tam novi quam veteris testamenti pagina decimas dandas esse proclamat" (Colomanus, 25. Bak et al. 1999, 26).

10 „Presbyteri et abbates, seu cuiuslibet personae dignitatis, ecclesiae decimationem persolvant, in cuius territorio agriculturam excercent aut vindemiant" (Colomanus, 66. Bak et al. 1999, 30).

${ }_{11}$ „Decretum est in sancta synodo ac omnibus, ut episcopis populus sanctae ecclesiae decimas omnium quae possident, servi vero ecclesiae parochiano presbytero tres denarios impendant" (Syn. Strig., 90. Bak et al. 1999, 65). 
povinný odvádzat’ desiatky z oviec, obilia či vínnych pivníc. ${ }^{12}$ Zlatá bula Ondreja II. z roku 1222 sa napokon už len stručne zmieňuje o povinnosti odovzdávat desiatky vo víne a obilí miesto ich odvádzania v peniazoch. ${ }^{13}$

Královské zákonníky z obdobia vlády Arpádovcov tak v hrubých obrysoch načrtávajú panovníkmi podporovaný nárok biskupov na desiatky. Zároveň naznačujú tendenciu presmerovávat desiatky ludí darovaných cirkvi smerom ku kostolom. Postupne sa menili aj podmienky, za ktorých platili desiatky príslušníci duchovného stavu. Kolomanove staršie zákony ešte obsahujú zmienky o povinnosti reholného kléru odvádzat desiatky biskupom, I. Ostrihomská synoda však už mníchov od platenia desiatkov sčasti oslobodzuje. Nemožno pochybovat', že sa na prelome 11./12. storočia formovali nariadenia o desiatku pod výrazným vplyvom aktívne vystupujúceho episkopátu. V tomto období zrejme prichádzalo k zvýšenému náporu biskupov na predchádzajúce výsady nárokované opátstvami, predovšetkým na exempčnú právomoc královských kláštorov, práva opátov používat biskupské insígnie a na výber desiatkov. D̃alšiu hrozbu predstavovala pre kláštory (dalo by sa tu však uvažovat o cirkevných inštitúciách všeobecne) cirkevná politika krála Kolomana a $\mathrm{s}$ ňou súvisiaci nápor svetskej moci na ich hospodárske privilégiá a majetky (podrobne Font 1999, 42-47). Niekde k začiatku 12. storočia tak zrejme siaha aj zvýšené úsilie pannonhalmských opátov o zabezpečenie starších práv kláštora prostredníctvom pápežských konfirmácií.

Prvý náznak ohrozenia šomodských desiatkov náležiacich Pannonhalmskému opátstvu je možné hladat’ už v pápežskej listine Paschalisa II. z roku 1102. Podla zákonodarstva aktuálne vládnuceho Kolomana mali byt’ výnosy kláštorov a d’alších cirkevných inštitúcií z rybolovu redukované na mieru, ktorá stačila na obživu kléru. Panovník nemal siahat iba na hospodárske výsady darované cirkvi ešte králom Štefanom. ${ }^{14} \mathrm{~V}$ dobe kulminujúceho kultu svätého krála sa tak stávali kláštorné privilégiá zaštítené menom sv. Štefana jediným účinným prostriedkom voči cirkevnej politike Kolomana a sekularizačným tendenciám. Nepochybne na žiadost' opáta Petra tak dal potvrdit' Paschalis II. Pannonhalme držbu deviatich kostolov s príslušenstvom na území vesprímskej, rábskej a ostrihomskej (arci)diecézy, d’alej staršie cirkevné privilégiá a desiatky, ktoré mal král' Štefan zabezpečit kláštoru ich „kúpou“ od Vesprímskeho biskupstva (decimae vero, quas Stefanus rex ab ecclesia Sancti Michahelis emit), teda pravdepodobne ich výmenou za královský dvorec (Cortou) s príslušnými príjmami a obyvatel'stvom (Györffy 1992, 331-334, č. 117). Zvyšujúcu sa potrebu právnej fixácie majetkov, privilégií a desiatkov Pannonhalmského kláštora zvýrazňujú $\mathrm{v}$ priebehu 12. storočia aj pápežské listiny Alexandra III., Urbana III. a Kolomana III. z poslednej tretiny 12. storočia. (Erdélyi 1902, 606-608, č. 18; 612-613, č. 24; 613-614, č. 25). Výzva Alexandra III. z roku $1181 \mathrm{k}$ zachovávaniu práv opátstva (eorum libertates custodire) už napokon smerovala výlučne k uhorským (arci)biskupom (Erdélyi 1902, 609, č. 20). Otázka oprávnenosti nárokov pannonhalmských opátov či vesprímskych biskupov na šomodské desiatky tak bola velmi pravdepodobne aktuálna už v priebehu 11./12. storočia. Nedostatok zmienok o starších sporoch tu možno spájat', skôr ako s absenciou rozporov, s nedostatočným spísomňovaním právnych aktov počas dlhého obdobia doznievajúcej právnej tradície založenej na staršom zvykovom práve. Podla svedectva zachovaných písomných prameňov sa však napokon desiatkové spory vystupňovali až v druhej dekáde 13. storočia.

Dôvody vzniku sporov o šomodské desiatky sa tradične hladajú v príchode ambiciózneho a mimoriadne schopného opáta Uriáša do Pannonhalmy. Primárne motívy, ktoré klerikov do týchto sporov vháňali, možno pritom spájat predovšetkým s narastajúcou ekonomickou výnosnostou

2 Syn. Strig., 64. Bak et al. 1999, 64.

13 Bak et al. 1999, 34.

14 „Similiter decrevimus piscinas monasteriis et ecclesiae datas, alias quidem reddere, sed necessarias quotidiano fratrum usui relinquere, nullas vero nisi superfluas auferre" (Colomanus, 16. Bak et al. 1999, 26). 
desiatkovej platby. Na začiatku 13. storočia možno pozorovat zvýšené úsilie reholného kléru o výber desiatkov z území v kláštornej držbe, prípadne z farských obvodov kostolov pod správou opátov. Tieto dôvody stáli aj za vypuknutím sporov o desiatky medzi benediktínskymi kláštormi v Pannonhalme a Somogyvári. Predstavy francúzskych mníchov v Somogyvári o nároku na desiatu čast príjmov z reholných majetkov, vrátane samotného mesta Somogyvár, znamenali zrejme dočasné presmerovanie vyberaných desiatkov $\mathrm{k}$ pivniciam a sýpkam tejto fílie francúzskeho opátstva v St. Gilles. Listina Ostrihomského arcibiskupstva z roku 1210 však už zároveň dokladá prvé úspechy opáta Uriáša v desiatkových sporoch. Ostrihomský arcibiskup Ján a komes Tibor potvrdili ako zmierovací sudcovia právo Uriáša na desiatky zo šomodského vína a na tri štvrtiny desiatkov kaplnky sv. Petra v meste Somogyvár. Ročné príjmy somogyvárskych opátov $\mathrm{z}$ desiatkov sa tak obmedzili na 80 sudov vína pre potreby jeho mníchov (Wenzel 1861, 102-104, č. 59). Gilbertov nástupca Herveus súdne rozhodnutie niekolko rokov v plnej miere rešpektoval a z listiny opáta vyplýva, že tak činil v záujme zachovania dobrých vztahov s predstaveným Pannonhalmského kláštora (Erdélyi 1902, 632, č. 45). V roku 1238 opätovne riešil palatín Dionýz stažnosti Uriáša ohladom zadržiavania jemu náležiacej desiatej časti z úrody, statkov, vínnych pivníc, hospodárskeho zvieratstva a desiatkov kaplnky sv. Petra (Erdélyi 1902, 761-762, č. 176). Francúzski opáti mali teda tendenciu, pravda za cenu istých kompromisov, nárokom Uriáša skôr ustupovat'. Desiatky kaplnky sv. Petra na najbližšom a najvýnosnejšom majetku opátstva napriek tomu pre predstavených kláštora ostávali, najmä po nástupe nových opátov, nad’alej potenciálnym zdrojom kláštorných príjmov.

$\mathrm{K}$ intenzívnejším atakom Uriáša voči právam vesprímskych biskupov na desiatky z územia celého Šomodského komitátu prichádzalo až od roku 1211, teda za episkopátu Roberta z Lutychu. Biskup západoeurópskeho pôvodu pôsobil najneskôr od roku 1207 ako královský kancelár Ondreja II., o dva roky bol investovaný ako vesprímsky biskup a svoju cirkevnú kariéru zavŕšil v roku 1227 ako ostrihomský arcibiskup. Robert bol navyše diplomatom v službách krála - silná pozícia na královskom dvore a osobné schopnosti mu v nasledujúcich rokoch umožnili úspešne hájit práva vesprímskych biskupov v oblasti ekonomických a cirkevných výsad biskupstva. Na sklonku roka 1211 bol biskup vyslaný panovníkom do Ríma, kde mali jeho diplomatické schopnosti poslúžit pri urovnávaní kompetenčných sporov medzi ostrihomským a kaločským arcibiskupom (Erdélyi 1902, 152). Tu sa dostal pred pápežom do priamej konfrontácie s osobne prítomným pannonhalmským opátom Uriášom. Predstavený Pannonhalmského kláštora napádal predovšetkým cirkevnú politiku biskupa v otázke výberu šomodských desiatkov. Podla podania Uriáša zbavoval Robert z Lutychu slobodné služobníctvo biskupa (conditionales homines), zvonárov (pulsatores) a d’alších služobníkov cirkvi na jeho diecéznom území desiatkovej povinnosti. Biskup d’alej odmietal na tažšie prístupných miestach v periférnych oblastiach komitátu zakročit voči pastierom svíń, ktorí dlhodobo neodvádzali desiatok, a odnímal kostolom a kaplnkám cirkevnú príslušnost' k opátstvu, čím oberal kláštor o štvrtinový podiel z desiatkov. Uriášova stažnost’ smerovala aj ku kňazom, ktorí skupovali od služobníkov krála víno ešte pred výberom desiatkov, čím opátstvo prichádzalo o dalšiu čast̉ desiatkovej platby. Opát žiadal pápeža o zakročenie voči zadržiavaniu desiatkov biskupom a o presmerovanie odvádzania všetkých šomodských desiatkov do držby opátstva tak, ako to nariad’ovali už privilégiá Paschalisa II. a sv. Štefana. ${ }^{15}$

Vesprímsky biskup prešiel do okamžitej protiofenzívy. Pred pápežom žiadal predovšetkým navrátenie šomodských desiatkov, pokial opát nebude schopný predložit relevantný dôkaz o nespochybnitel’nom práve na ne. Robert z Lutychu zároveň požadoval od opáta náhradu

15 „[...] petebas, ut idem episcopus non impediat nec faciat impediri, quominus omnes, qui in Simigiensi comitatu consistunt, de omnibus, que possident, decimas integras sibi solvant, sicut plene in privilegio felicis memorie Paschalis pape ac sancti regis Stephani continetur" (Erdélyi 1902, 634, č. 48). 
za neprávom vyberanú štvrtinu desiatkov na zveladenie a opravu cirkevných budov (quarta fabrice ad reparandam ecclesias), ktorá náležala biskupom. Vesprímsky biskup sa ohradzoval aj voči obmedzeniam cirkevných právomocí, ktoré spadali pod práva episkopátu. Opát mal hmotne zabezpečit pohostenie biskupa počas jeho prítomnosti na šomodských majetkoch opátstva. Biskup d’alej žiadal o zbúranie kaplniek vo Füzítő v oblasti Zselicsského lesa a v dedine (pastierov svíň) sv. Ladislava, ktoré boli postavené bez jeho súhlasu, zároveň o navrátenie kaplniek v Tepej a Köröshegy (Erdélyi 1902, 634, č. 48). Stojí za zmienku, že posledné dve menuje v držbe Pannonhalmského opátstva už pápežská listina Paschalisa II. z roku 1102. O argumentačných schopnostiach Uriáša na druhej strane niet pochýb, pápež tak bol ochotný potvrdit nároky opáta, pravda pod podmienkou, že Uriáš predloží autentickú listinu Štefana trom uhorským prelátom na porovnanie s jej predloženým prepisom. V otázke cirkevných právomocí na šomodskom území mali byt do vynesenia rozsudku zachované nároky vesprímskeho biskupa s dodatkom, ktorý predsa len ponechával opátovi istý manévrovací priestor (Fejér 1829a, 134).

Protiútok biskupa naznačuje sebavedomie „svetského“ preláta, ktoré vychádzalo zo všeobecne uznávaného, aj uhorským královským zákonodarstvom explicitne zdôrazňovaného práva episkopátu na desiatky z územia vlastnej diecézy. Pápežská listina Inocenta III. z roku 1212 a konečné rozhodnutie pápeža z roku 1215 zároveň poodhalujú dalšie súvislosti. Uriáš prichádzal do Ríma s nárokmi, ktoré mala argumentačne podporit pápežská listina Paschalisa II. a prepis údajnej privilegiálnej listiny sv. Štefana. Autentickost posledne menovanej písomnosti bola zrejme okamžite spochybnená Robertom z Lutychu. Inocent III. totiž potvrdzoval a prepisoval opátom predloženú a biskupom niekol'kokrát spochybnenú privilegiálnu listinu krála Štefana, aby už v budúcnosti nemohla byt’ označená za listinný podvrh. ${ }^{16}$ Desiatky z celého územia Šomodského komitátu boli v plnej miere priznané opátovi, vrátane biskupom požadovanej štvrtiny desiatkov určenej na opravu cirkevných stavieb. Výnosy z farských obvodov kostolov a kaplniek opátstva na diecéznom území biskupa mali pripadnút opátovi, cirkevno-právne mali nad’alej podliehat Vesprímskemu biskupstvu. Pápežské rozhodnutie bolo teda vo väčšine sporných bodov priaznivo naklonené opátstvu. Naopak, ústupky voči nárokom biskupa sa obmedzili na priznanie cirkevnej príslušnosti kostolov a na každoročnú platbu za stratu štvrtinového podielu z desiatkov vo výške 10 mariek, ktoré mali byt’ vyplácané biskupstvu opátom (Erdélyi 1902, 634-635, č. 48).

Na prvý pohlad tak môže zarážat skutočnost', že na pápežské rozhodnutie rezignoval už o tri roky práve pannonhalmský konvent. Nadchádzajúci sled udalostí však vhodne ilustruje pomerne nestabilné pozície opátstva na odlahlom šomodskom území pod správou vesprímskeho biskupa. Krehká rovnováha nastolená Inocentom III. sa naštrbila po odchode Uriáša do Svätej zeme v rámci križiackej výpravy Ondreja II. (jeseň 1217). Nasledovalo opätovné zadržiavanie desiatkov biskupom, napádanie úradníkov opátstva, následné odmietnutie vyplatenia ročnej kompenzácie za desiatky biskupstvu, cesta priora opátstva do Ríma (január 1218) a snaha konventu o zrušenie pôvodného rozhodnutia a vydania nového. ${ }^{17}$ Za pozadím krokov pannohalmských mníchov možno hladat predovšetkým nedodržiavanie pôvodných nariadení Inocenta III., podcenit však nemožno ani nespokojnost̉ konventu s odvádzaním ročného poplatku a s cirkevno-právnym

16 „[...] vos ad iuris vestri defensionem privilegium Sancti Stephani regis produxistis, quod idem episcopus multis modis nisus est inprobare. Sed vobis e contrario diversis racionibus resistentibus ipse tandem in sua intentione defecit. Ne igitur ipsi privilegio ulterius possit opponi vicium falsitatis, illud quod contradicto iudicio comperimus esse verum, de verbo ad verbum presenti pagine iussimus annotari" (Erdélyi 1902, 633, č. 47).

$17 \mathrm{O}$ udalostiach informujú listiny pápeža Honoria III. adresované vesprímskemu biskupovi z 1 . februára a 3. marca 1218 (Fejér 1829b, 258; Erdélyi 1902, 644, č. 56). 
podriadením šomodských kostolov a kaplniek opátstva biskupstvu. ${ }^{18}$ Pannonhalmskí opáti sa totiž už po celé 12 . storočie snažili zabezpečovat výnimočné postavenie opátstva pápežskými listinami, ktoré ich oslobodzovali od akýchkolvek zásahov diecéznych biskupov. $Z$ tohto pohladu mohlo byt' rozhodnutie Inocenta III. vnímané mníchmi ako zásah do tažko vybojovanej kláštornej exempcie. Za dôrazom pannonhalmského konventu na dodržiavanie cirkevných výsad možno pritom opätovne hladat predovšetkým ekonomické motívy. Nejednoznačne definované právomoci opátov pri d’alšom rozširovaní počtu šomodských kostolov a kaplniek totiž mohli ohrozovat aj perspektívu potenciálneho rastu desiatkových príjmov kláštora. Práve kvôli zefektívneniu výberu desiatkov a d’alších príjmov mohlo prichádzat za opáta Uriáša k systematickejšiemu scelovaniu kláštorných majetkov na území Šomodského komitátu ich výmenou, kúpou a predajom. Relatívne husto osídlené majetkové komplexy v kláštornej držbe poskytovali vidinu vyšších príjmov, odvody z nich však mohli byt’ na diecéznom území Vesprímskeho biskupstva aj pod účinnejšou kontrolou kláštornej byrokracie. Proces stmelovania šomodských majetkov opátstva bol v období pred tatárskym vpádom ukončený ziskom starej šomodskej lokality Stoličnobelehradského prepošstva v Bogáte. Ned’aleko južných brehov Blatenského jazera sa tak dotvorila jedna z najludnatejších enkláv majetkov Pannonhalmského opátstva v 13. storočí. ${ }^{19}$

Rozhodnutie prelátov poverených pápežom Honoriom III. vynesením rozsudku v podstate ponechávalo $\mathrm{v}$ platnosti status quo. Tento stav umožnil Uriášovi v nasledujúcich rokoch zefektívnit v minulosti skôr teoreticky nárokovaný výber desiatkov. Nespokojnost’ vesprímskeho biskupa mala byt’ nadalej kompenzovaná ročne odvádzaným poplatkom za stratu štvrtinového podielu $\mathrm{z}$ nich. V roku 1227 však prepukol neriešený problém zakladania nových kostolov na území vesprímskej diecézy. V bezprostrednej blízkosti jednej z najludnatejších šomodských dedín v kláštornej držbe (Tepej nedaleko spomenutej lokality Bogát) dal postavit Uriáš bez povolenia biskupa kaplnku (pravdepodobne sv. Jakuba) na lokalite s príznačným názvom Remete. Cirkevná stavba bola následne vypálená a mnísi napadnutí lud’mi vesprímskeho biskupa (Wenzel 1861, 246, č. 144). Na druhej strane sa zachovala aj zmienka o protestoch Uriáša proti biskupom postavenej kaplnke v blízkosti kláštornej kaplnky sv. Ladislava v Zselicskom lese. Nástupca Roberta z Lutychu Bertalan bol následne nútený priznat pred pápežským legátom Jakubom právo opátstva na štvrtinový podiel z desiatkov vo farskom obvode biskupom postavenej kaplnky. Uriáš následne presadil, nepochybne zásluhou silného postavenia na královskom dvore, aj obnovu zhorenej kaplnky v Remete, ku ktorej mu pričlenil Ondrej II. ako náhradu za vzniknuté škody dve poplužia. ${ }^{20}$ Intenzita desiatkových sporov s Vesprímskym biskupstvom sa už následne po dosadení Roberta z Lutychu na arcibiskupský stolec v Ostrihome výrazne zmiernila.

V rozmedzí rokov 1210 - 1232 sa Uriáš súdil o šomodské desiatky aj so Záhrebským biskupstvom. Požiadavku na desiatky z úrody, lesov, hospodárskeho zvieratstva, daní, mýt a na desiatky troch šomodských kaplniek (sv. Kríža, sv. Trojice a sv. Barnabáša) predložil opát pred pápežom Inocentom III. už v roku 1210, následne na všeobecnej synode na jeseň roku 1215. Od tohto roku sa záhrebskí biskupi voči nárokom opáta, ktoré boli opät argumentačne podporené pápežskými listinami z 12. storočia a privilegiálnou listinou sv. Štefana, bránili nepretržitou držbou desiatkov za ich predchodcov. Na napadnuté desiatky šomodských kaplniek si biskupi nárokovali ako na súčast' desiatkovej platby vyberanej na vlastnom diecéznom území. K dohode medzi sporiacimi sa stranami prišlo až po dlhých 22 rokoch. Podla dvoch listín pápeža Gregora IX. z roku 1232 sa

18 V týchto príčinách videl obnovenie sporu už László Erdélyi $(1902,155)$.

19 Ku genéze kláštorných majetkov pred tatárskym vpádom pozri podrobnejšie László Solymosi (1996, 515-526).

20 Priebeh sporov v dvadsiatych rokoch 13. storočia vyčerpávajúco spracoval už László Erdélyi (1902, 156-157). 
Uriáš desiatkov na diecéznom území Záhrebského biskupstva za riekou Drávou zriekol za cenu pomerne rozsiahlych ústupkov. Opát totiž získal ako kompenzáciu desiatky a majetky náležiace k sporným kaplnkám a odškodné za straty a súdne náklady vo výške 500 mariek. Konečná suma mala byt’ opátstvu vyplatená v kvalitných, za vlády Ondreja II. v Uhorsku už pomerne rozšírených friesachských denároch $\mathrm{v}$ dvoch splátkach. ${ }^{21}$

Prvé úspechy v desiatkových sporoch a argumentačná sila tzv. privilegiálnej listiny krála Štefana vháňala Uriáša do konfrontácie s d’alšími cirkevnými inštitúciami. ${ }^{22}$ V súvislosti s nevšednou šírkou súdnych sporov sa tlačí do popredia otázka, či za nimi skutočne možno vidiet’ len silnú osobnost' opáta, teda s nástupom Uriáša spájané systematické úsilie o právnu legitimizáciu dávno existujúcich nárokov na cirkevné desiatky z územia Šomodského komitátu. Na dôvody prepuknutia desiatkových sporov je totiž možné hladiet’ aj z podstatne širšej perspektívy. Od prelomu 12./13. storočia sa $\mathrm{z}$ ekonomického hladiska postupne presúval dôraz od darovanej pracovnej sily a naturálnej produkcie $\mathrm{k}$ držbe pôdy a $\mathrm{k}$ peňažným príjmom, ktoré sa s ňou spájali. ${ }^{23}$ Do tohto kontextu možno zasadit aj desiatkové spory. Význam desiatkov sa mohol v celom stredoeurópskom priestore zvyšovat predovšetkým v dôsledku nárastu hospodárskej produkcie a počtu obyvatel'stva, podcenit však nemožno ani stále efektívnejší systém správy majetkov vo vlastnej réžii cirkevných inštitúcií. ${ }^{24} \mathrm{~V}$ súvislosti so spormi o šomodské desiatky možno pritom nachádzat zaujímavé analógie aj v přemyslovských Čechách. Najvýznamnejšiu paralelu k šomodským desiatkom predstavujú spory o desiatky z troch severočeských provincií (Bilíňsko, Děčínsko, Litoměřicko) medzi Břevnovským opátstvom a Pražským biskupstvom za biskupa Ondreja. „Břevnovské“ desiatky z týchto provincií sa považujú, obdobne ako šomodské, za donáciu z konca 10. storočia, ktorou mal hmotne zabezpečit prvý břevnovský konvent pražský biskup a údajný spoluzakladatel' kláštora sv. Vojtech. ${ }^{25}$ Desiatky z troch severočeských provincií však pripomínajú prípad šomodských desiatkov aj samotnou dobou a okolnostami vzniku desiatkových sporov. Ku konfirmácii pôvodného papyrusového originálu pápežského privilégia Jána XV. pre kláštor v Břevnove pristúpili břevnovskí mnísi v roku 1224, teda bezprostredne po intenzívnom spore medzi Přemyslom Otakarom I. a pražským biskupom Ondrejom v rokoch 1216 - 1222 (podrobne Žemlička 1981, 704-730). Konfirmáciu tak možno vnímat ako reakciu břevnovských benediktínov na silnejúci tlak svetskej cirkvi. Za obdobné možno považovat aj mechanizmy, ktorými mnísi v Pannonhalme a v Břevnove pristúpili k obrane ohrozených desiatkov. S velkou pravdepodobnostou sa totiž práve $\mathrm{v}$ dôsledku nastupujúcich desiatkových sporov uchylovali opáti týchto kláštorov k spísaniu interpolovaných listín, ktoré mali nahradit staršie, obsahom a výpovednou hodnotou už nevyhovujúce písomnosti. ${ }^{26}$ Tzv. břevnovské falzá sa v tejto podobe zachovali dodnes.

V sporoch o šomodské desiatky bola rozhodujúcim argumentom tzv. privilegiálna listina krála sv. Štefana. ${ }^{27}$ Príklad tohto umne skonštruovaného falza, či skôr interpolácie výstižne dokladá

${ }^{21}$ O sporoch so Záhrebským biskupstvom platí konštatovanie z predchádzajúcej poznámky, v rámci príspevku sa im tak podrobnejšie venovat nebudem. K hodnote friesachských denárov a k okolnostiam ich vyplácania v Uhorsku za vlády Ondreja II. pozri Bálint Hóman (1916, 79-82, 289-314).

22 Uriáš sa intenzívne súdil predovšetkým s benediktínskym opátstvom v Somogyvári, vesprímskymi biskupmi, Ostrihomským arcibiskupstvom, vesprímskymi johanitmi a Stoličnobelehradskou kapitulou.

23 Podrobne pozri Bloch 2010, 79-92; Bloch 1967, 230-243. Ide, prirodzene, o zovšeobecnenie podstatne variabilnejšieho vývoja, ktorého počiatky siahajú v západoeurópskom prostredí hlboko do 11. storočia.

${ }^{24} \mathrm{~K}$ dopadom vrcholnostredovekej transformácie v tzv. „dlhom“ 13. storočí na reholné prostredie pozri Borovský 2010, 307-318.

25 Friedrich 1914 - 1917, 347-350, č. 375.

26 K analýze privilégia Jána XV. pre Břevnovský kláštor pozri Gustav Friedrich (1905, 12-21); Václav Hrubý (1920, 117-126); novšie Josef Žemlička (1993, 25-39).

27 Ku genéze výskumu listiny pozri Gábor Thoroczkay (1996, 90-109). 
nároky, ktoré pri predkladaní dokazovacích prostriedkov kládla na sporiace sa strany stredoveká právna tradícia. Účinnosț týchto dôkazov totiž spočívala predovšetkým v preukázatelnej starobylosti ich pôvodu. Z tohto pohladu nie je prekvapujúca ani následná snaha Uriáša o konfirmáciu privilegiálnej listiny krála Štefana Ondrejom II. v roku 1213. V záujme zadostučinenia spravodlivosti a právu (ut ius exigit) žiadal Uriáš panovníka o potvrdenie a obnovenie (corroborare et renovare) rozhodnutia, ktorým disponovalo opátstvo od dávnych čias (tante prerogative, quam ex longa antiquitate possidet). Žiadost' opáta bola motivovaná odstránením akýchkolvek úkladov či pochybností (ad recidendum quamlibet calumpniam) - v zmienke sa už zretelne odrážajú nedávne udalosti, ktoré samotnú potrebu konfirmácie bezprostredne vyvolali (Erdélyi 1902, 625, č. 39).

Širšie koncipované práce západných medievalistov pozadí stredovekého falšovania naznačujú, že pre predstavitelov cirkevných elít nepredstavovalo prirad’ovanie vlastných textov $\mathrm{k}$ menám a pečatiam adorovaných panovníkov morálnu dilemu. ${ }^{28} \mathrm{Aj}$ príklad šomodských desiatkov dokladá, že sa nezriedka jednalo o jediný účinný spôsob, ako právne ukotvit výsady a majetky cirkevných inštitúcií. V desiatkových sporoch bolo pritom královské zákonodarstvo v Uhorsku jednoznačne na strane episkopátu. Nárokmi biskupov mohli v tomto smere otriast' iba dôkazy, ktoré sa opierali o autoritu svätého krála a preukázanú starobylost̉ nárokovaných práv. V súvislosti s desiatkovými spormi Uriáša so záhrebskými biskupmi stojí na druhej strane za pozornost', že sa už za riekou Drávou argumenty opáta nepresadili. Jedným z rozhodujúcich činitelov tu však opät mohla byt' existujúca staršia tradícia. Z diecézneho územia záhrebských biskupov totiž šomodské desiatky Pannonhalme nikdy predtým neplynuli. Zainteresovaným stranám a predstavitel’om súdnej moci musel byt nesúlad medzi rozsahom komitátneho územia v čase donácie desiatkov Pannonhalmskému kláštoru a pomermi z 13. storočia celkom zrejmý - presmerovanie desiatkovej platby by v tomto prípade narúšalo od prelomu 11./12. storočia existujúci stav. Aj pod dojmom tejto skutočnosti sa tak mohla argumentačná prevaha opáta na území Záhrebského biskupstva oslabovat'. Otáznym ostáva, do akej miery by dokázal pannonhalmský opát zabezpečit plynulý výber desiatkov z odlahlej, tažko prístupnej a logisticky nezabezpečenej oblasti. Ani štedrá kompenzácia vyplatená Pannohalme záhrebským biskupom tak nakoniec nemusela byt vnímaná medzi početnými desiatkovými spormi iniciovanými Uriášom ako jednoznačný neúspech.

\section{REFERENCES}

\section{Primary sources}

Bak, János M. et al. (eds.). 1999. Decreta regni mediaevalis Hungariae I (1000 - 1301). Idyllwild. Fejér, Georgius (ed.). 1829a. Codex diplomaticus Hungariae ecclesiasticus ac civilis I. Budae. Fejér, Georgius (ed.). 1829b. Codex diplomaticus Hungariae ecclesiasticus ac civilis III. Budae. Friedrich, Gustav (ed). 1914-1917. Codex diplomaticus et epistolaris regni Bohemiae I. Pragae. Györffy, György (ed.). 1992. Diplomata Hungariae Antiquissima. Accedunt Epistolae et Acta ad historiam Hungariae pertinentia. Budapest.

Wenzel, Gusztáv (ed.). 1861. Codex diplomaticus Arpadianus continuatus. Árpád-kori új okmánytár I. Pest.

28 Poukázat možno v tejto súvislosti predovšetkým na rozsiahly výstup z medzinárodnej konferencie venovanej stredovekému falšovaniu z rôznych perspektív: Fälschungen im Mittelalter. Internationaler Kongress der Monumenta Germaniae Historica. München, 16. - 19. September 1986 (I-V). Schriften der Monumenta Germaniae Historica, Band 33. Hannover 1988. 
Závodszky, Levente (ed). 1904. A Szent István, Szent László és Kálmán korabeli törvények és zsinati határozatok forrásai. Budapest.

\section{Secondary sources}

Bloch, Marc. 2010. Feudální společnost. Praha.

Bloch, Marc. 1967. Natural economy or money economy: a pseudo-dilemma. In Land and work in mediaeval Europe. London, 230-243.

Borovský, Tomáš. 2010. Několik otázek nad přemyslovským 13. stoletím. In Wihoda, Martin Reitinger, Lukáš (eds.). Proměna středovýchodní Evropy raného a vrcholného středověku. Mocenské souvislosti a paralely. Brno, 307-318.

Erdélyi, László. 1902. A Pannonhalmi Szent-Benedek rend története I. Budapest.

Druga, Marek. 2019. Comitatus decimationem abbati subiugarem. K pôvodu donácie šomodských desiatkov. In Forum Historiae 13/2, 75-88.

Érszegi, Géza. 1996. Szent István pannonhalmi oklevele (Oklevéltani-filológiai kommentár). In Takács, Imre (ed.). Mons Sacer 996 - 1996 I. Pannonhalma, 47-89.

Fälschungen im Mittelalter. Internationaler Kongress der Monumenta Germaniae Historica. München, 16. - 19. September 1986 (I-V). In Schriften der Monumenta Germaniae Historica, Band 33. Hannover 1988.

Font, Márta. 1999. Könyves Kálmán és kora. Szekszárd.

Friedrich, Gustav. 1905. O privilegiu papeže Jana XV. daném v r. 993 klášteru Břevnovskému. In Český časopis historický 11, 12-21.

Hóman, Bálint. 1916. Magyar pénztörténet 1000 - 1325. Budapest.

Hrubý, Václav. 1920. Falsa břevnovská. In Český časopis historický, roč. 26, 117-126.

Kristó, Gyula. 2002. Joghatóság Somogy felett Szent István korában. In Veszprémy, László (ed.). Szent István és az államalapítás. Budapest, 449-453.

Lados, Tamás. 2016. Megjegyzések a pannonhalmi gyermektized történetéhez. In Magister historiae II. Válogatott tanulmányok a 2014-ben és 2015-ben megrendezett középkorral foglalkozó, mesterszakos hallgatói konferenciák előadásaiból. Budapest, 73-98.

Solymosi, László. 1996. Albeus mester összeírása és a pannonhalmi ápátság tátárjárás előtti birtokállománya. In Takács, Imre (ed.). Mons Sacer 996 - 1996. Pannonhalma 1000 éve I. Pannonhalma, 515-526.

Solymosi, László. 2002. Püspöki joghatóság Somogyban a 11. században. In Veszprémy, László (ed.). Szent István és az államalapítás. Budapest, 439-448.

Solymosi, László. 2016. Szent István és a pannonhalmi apátság somogyi tizedjoga. In Somorjai, Ádám - Zombori, István (eds.). Episcopus, archiabbas, Benedictinus, historicus ecclesiae. Tanulmányok Várszegi Asztrik 70. születésnapjára. Budapest, 11-24.

Thoroczkay, Gábor. 1996. Szent István pannonhalmi oklevelének historiográfiája. In Takács, Imre (ed.). Mons sacer 996 - 1996 I. Pannonhalma, 90-109.

Zsoldos, Attila. 2002a. Somogy és Visegrád megye korai története, valamint a „várelemek spontán expanziója“. In Veszprémy, László (ed.). Szent István és az államalapitás. Budapest, 471-477.

Zsoldos, Attila. 2002b. Somogy megye korai történetének forrásairól. In Veszprémy, László (ed.). Szent István és az államalapítás. Budapest, 451-461.

Žemlička, Josef. 1993. K hodnověrnosti listiny Jana XV. pro klášter v Břevnově (31.V.993). In Bláhová, Marie - Hlaváček, Ivan (eds.). Milénium břevnovského kláštera (993 - 1993). Sborník statí o jeho významu a postavení v českých dějinách. Praha, 25-39. 
Žemlička, Josef. 1981. Spor Přemysla Otakara I. s pražským biskupem Ondřejem. In Československý časopis historický 29, 704-730.

Mgr. Marek Druga, PhD.

Slovak Academy of Sciences

Institute of History

P. O. Box 198

Klemensova 19

81499 Bratislava

Slovakia

marek.druga@savba.sk 